\title{
Plant growth regulators promote growth and yield of summer tomato (lycopersicone sculentum Mill.)
}

\author{
M Rahman ${ }^{1}$, MA Nahar ${ }^{2}$, MS Sahariar ${ }^{1}$, MR Karim ${ }^{1 *}$ \\ ${ }^{1}$ Department of Horticulture, Bangladesh Agricultural University, Mymensingh, Bangladesh; ${ }^{2}$ Department of \\ Biotechnology, EXIM Bank Agricultural University, Bangladesh
}

\begin{abstract}
An experiment was conducted at the Horticulture Farm of Bangladesh Agricultural University, Mymensingh to test the impact of plant growth regulators on growth and yield of summer tomato. The experiment consisted of two tomato varieties viz. BARI Hybrid Tomato-4 and BARI Hybrid Tomato-8 and four types of plant growth regulator (PGR)viz.,(i) control (without PGR), (ii) 4-CPA (4-chlorophenoxy acetic acid), GA 3 (gibberellic acid) and 4-CPA $+\mathrm{GA}_{3}$. The two-factor experiment was laid out in randomized complete block design with three replications. The results of the experiment revealed that significant variations were observed for most of the characters studied. At 75 DAT, the tallest plant $(79.35 \mathrm{~cm}$ ), number of flowers and fruits (38.11 and 19.04, respectively) plant ${ }^{-1}$, individual weight $(58.44 \mathrm{~g})$ and fruit yield $\left(22.75 \mathrm{t} \mathrm{ha}^{-1}\right)$ were found in BARI Hybrid Tomato-8.At 75 DAT the maximum plant height $(87.90 \mathrm{~cm})$, number of flowers and fruits $(49.04$ and 21.9, respectively) plant ${ }^{-1}$, individual fruit weight (61.16 g), and fruit yield $\left(27.28 \mathrm{tha}^{-1}\right)$ were found when 4-CPA + $\mathrm{GA}_{3}$ applied together, whereas the minimum for these characters were recorded from control plants. In case of combined effect of variety and plant growth regulator, the maximum plant height $(87.90 \mathrm{~cm})$, number of flowers and fruits (49.04 and 21.91, respectively) plant ${ }^{-1}$ individual fruit weight (61.16 g) and fruit yield (27.28 $\mathrm{t} \mathrm{ha}^{-1}$ ) were observed in BARI Hybrid Tomato-8 when treated with 4-CPA + GA 3 together, and the minimum for all these parameters were found in control plants. The results of the present study suggest thatboth 4-CAP and $\mathrm{GA}_{3}$ together can be practiced for increasing summer tomato production for both the varieties.
\end{abstract}

Key words: Gibbrellin, 4-chlorophenoxy acetic acid, growth, yield, summer tomato

Progressive Agriculturists. All rights reserve

\section{Introduction}

Tomato (Lycopersicone sculentum Mill.) belongs to the family Solanaceae and is a self-pollinated crop. It is one of the popular, nutritive and important vegetable crops in Bangladesh which is receiving increased attention of the growers and consumers and made its position within few of the highest cultivated vegetables. Its food value is very rich because of higher contents of vitamins $\mathrm{A}, \mathrm{B}$ and $\mathrm{C}$ and also minerals like calcium which promote good health (Wilcox et al, 2003).

November-February is the period when congenial atmosphere remains for tomato cultivation in Bangladesh. Although tomato plants can grow under
*Corresponding Author: mrkarim1996@yahoo.com

a wide range of climatic conditions, they are extremely sensitive to hot and wet growing conditions, the weather which prevails in the summer season in Bangladesh (Ahmad, 2002). Tomato cultivation during March to September in Bangladesh is constrained due to the adverse weather of summer along with absence of heat tolerant varieties. Tomato requires day temperature of 21$28^{\circ} \mathrm{C}$ and moderately cool night temperature of $15-$ $20^{\circ} \mathrm{C}$ for proper fruit setting. High temperature (both day and night), humidity, rainfall and light intensity are the limiting factors of tomato production (Abdulla and Verkerk, 1968). High day and night 
temperature above $32^{\circ} \mathrm{C}$ and $21^{\circ} \mathrm{C}$, respectively, was reported as limiting factor to fruit-set due to an impaired complex of physiological process in the pistil, which results in floral or fruit abscission (Picken, 1984). Because of adverse weather especially high temperature and rainfall during March to September, traditional variety of tomato cannot be grown during summer in Bangladesh.

In some countries, tomatoes are commercially growing even at high temperature through application of plant growth regulators (PGRs). Gemici et al (2006) reported that application of auxin and gibberellins are effective in increasing both yield and quality of tomato. Application of certain PGRs like auxin and gibberellic acid (GA3) bring the possibility of tomato production under adverse environmental conditions. Those PGRs are used extensively in tomato to enhance yield by improving fruit set, size and number of fruits (Batlang, 2008; Serrani et al, 2007). Tomato fruit set was promoted by $\mathrm{GA}_{3}$ at low concentration (Khan et al, 2006). Synthetic auxin 4-CPA (4-chloro phenoxy acetic acid) reduced pre-harvest fruit drop with increased number of fruits per plant and yield (Sasaki et al, 2005). Application of 4-CPA is more effective during anthesis period than one week after anthesis (Poliquit et al, 2007). In fact the use of growth regulators had improved the production of tomatoincluding other vegetables in respect of better growth and quality, which ultimately led to generate interest between the scientists and farmers for commercial application of growth regulators. Tomato production in Bangladesh is largely affected due to adverse environmental conditions during summer season. However, information regarding the practical use of plant growth regulators in summer tomato production is not adequate. The present study was, therefore, undertaken to investigate the effect of different PGRs on the growth and yield of summer tomato.

\section{Materials and Methods}

The experiment was carried out at the Horticultural Farm of Bangladesh Agricultural University, Mymensingh during June2014 to October2014. Two- factor experiment consisted of four different levels of 4-chlorophenoxy acetic acid (4-CPA) i.e., $\mathrm{T}_{0}=$ control (without 4-CPA), $\mathrm{T}_{1}=4$-CPA @ 20 ppm, $\mathrm{T}_{2}$ =4-CPA @ 40 ppm and T3=4-CPA @ 60 ppm; and two varieties of summer tomato namely, BARI Hybrid Tomato- 4 and 8 were used in this study. The experiment was laid out in a randomized complete block design with three replications. Thirty-day-old seedlings were transplanted at the spacing of $60 \mathrm{~cm} \times$ $50 \mathrm{~cm}$. Manures and fertilizers were applied at the rate of cowdung12 t/ha, urea $450 \mathrm{~kg} / \mathrm{ha}$, Triple Super Phosphate (TSP) $350 \mathrm{~kg} / \mathrm{ha}$ and Muriate of Potash (MoP) $300 \mathrm{~kg} / \mathrm{ha}($ BARC, 2012).Both 4-CPA and $\mathrm{GA}_{3}$ were applied at a concentration of $20 \mathrm{ppm}$. Spraying was performed early in the morning to avoid rapid drying of the spray solution due to transpiration. Data were collected from five randomly selected plants from each plot and were statistically analyzed to find out the statistical significance of the experimental results. The means for all the treatments were calculated and the analyses of variance for all the characters were performed by $\mathrm{F}$ test. The significance of difference between the pairs of means was separated by LSD test at $5 \%$ and $1 \%$ levels of probability (Gomez and Gomez, 1984).

\section{Results and Discussion}

\section{Plant height}

Different plant growth regulators showed statistically significant variations on the plant height at 25, 50 and 75 days after transplanting (DAT).Plant height of two varieties of summer tomato under field conditions at 75 days after transplanting also showed significant difference (Table 1). BARI Hybrid Tomato-8 produced taller (79.35) plants than BARI Hybrid Tomato-4 (77.20).

In case of plant growth regulators, plant height at 75 DAT was significantly affected by the treatments (Table 2). The maximum $(86.75 \mathrm{~cm})$ plant height was measured in the combined application of plant growth regulators $\left(\mathrm{GA}_{3}+4-\mathrm{CPA}\right)$ where control treatment gave the minimum plant height $(63.90 \mathrm{~cm})$. Tomato variety and plant growth regulators had significant interaction effects on plant height at 50 and 75 DAT (Table 3). At 75 DAT, the highest 
(87.90 cm) plant height was measured in $\mathrm{V}_{2} \mathrm{~T}_{3}$ whereas $\mathrm{V}_{1} \mathrm{~T}_{0}$ showed the lowest $(63.00 \mathrm{~cm})$ plant height. This might be due to the effect of plant growth regulators on the vegetative part of the plant or may be helped more photosynthetes supplied to the fruits as number of fruits increased by plant growth regulators. Phookan and colleagues (1990) reported that when grown tomato in summer under plastic house conditions, the plant height ranged from $46.00 \mathrm{~cm}$ to $95.00 \mathrm{~cm}$ in an experiment with 29 hybrids of tomato and also found variations in plant height among the hybrids.

Table 1. Main effect of variety on growth, yield contributing characters and yield of summer tomato

\begin{tabular}{|c|c|c|c|c|c|c|c|}
\hline \multirow[b]{2}{*}{ Variety } & \multicolumn{3}{|c|}{ Plant height at } & \multirow{2}{*}{$\begin{array}{l}\text { No. of flowers. } \\
\text { Plant }^{-1}\end{array}$} & \multirow{2}{*}{$\begin{array}{l}\text { No. of } \\
\text { fruits. } \\
\text { plant }^{-1}\end{array}$} & \multirow{2}{*}{$\begin{array}{l}\text { Individual } \\
\text { Fruit. weight } \\
\text { (g) }\end{array}$} & \multirow{2}{*}{$\begin{array}{l}\text { Yield } \\
\left(\mathrm{t} \mathrm{ha}^{-1)}\right.\end{array}$} \\
\hline & $25 \mathrm{DAT}$ & $50 \mathrm{DAT}$ & 75 DAT & & & & \\
\hline $\mathrm{V}_{1}$ & 22.48 & 58.05 & 77.20 & 33.51 & 18.33 & 56.42 & 21.23 \\
\hline $\mathrm{V}_{2}$ & 22.95 & 60.60 & 79.35 & 38.11 & 19.04 & 58.44 & 22.75 \\
\hline $\operatorname{LSD}_{(0.05)}$ & 0.305 & 0.384 & 0.192 & 0.393 & 0.175 & 0.092 & 0.274 \\
\hline$(0.01)$ & 0.425 & 0.534 & 0.266 & 0.547 & 0.243 & 0.128 & 0.381 \\
\hline $\begin{array}{l}\text { Level of } \\
\text { significance }\end{array}$ & $* *$ & $* *$ & $* *$ & $* *$ & $* *$ & $* *$ & $* *$ \\
\hline
\end{tabular}

Table 2. Main effect of plant growth regulators (PGRs) on growth, yield contributing characters and yield of summer tomato

\begin{tabular}{|c|c|c|c|c|c|c|c|}
\hline \multirow[t]{2}{*}{ Treatment } & \multicolumn{3}{|c|}{ Plant height $(\mathrm{cm})$ at } & \multirow{2}{*}{$\begin{array}{l}\text { No. of } \\
\text { flowers. } \\
\text { Plant }^{-1}\end{array}$} & \multirow{2}{*}{$\begin{array}{l}\text { No. of } \\
\text { fruits. } \\
\text { plant }^{-1}\end{array}$} & \multirow{2}{*}{$\begin{array}{c}\text { Individual } \\
\text { Fruit. weight } \\
\text { (g) }\end{array}$} & \multirow{2}{*}{$\begin{array}{c}\text { Yield (t } \\
\text { ha }^{-1)}\end{array}$} \\
\hline & $25 \mathrm{DAT}$ & $50 \mathrm{DAT}$ & $75 \mathrm{DAT}$ & & & & \\
\hline $\mathrm{T}_{0}$ & 21.70 & 45.05 & 63.90 & 22.52 & 12.09 & 54.16 & 13.35 \\
\hline $\mathrm{T}_{1}$ & 22.55 & 60.40 & 77.85 & 35.67 & 19.34 & 56.83 & 22.40 \\
\hline $\mathrm{T}_{2}$ & 23.00 & 64.85 & 84.60 & 39.16 & 21.52 & 58.37 & 25.46 \\
\hline $\mathrm{T}_{3}$ & 23.60 & 67.00 & 86.75 & 45.88 & 21.79 & 60.36 & 26.77 \\
\hline $\operatorname{LSD}_{(0.05)}$ & 0.432 & 0.544 & 0.271 & 0.556 & 0.247 & 0.130 & 0.387 \\
\hline$(0.01)$ & 0.601 & 0.756 & 0.377 & 0.773 & 0.344 & 0.180 & 0.539 \\
\hline $\begin{array}{l}\text { Level of } \\
\text { significance }\end{array}$ & $* *$ & $* *$ & $* *$ & $* *$ & $* *$ & $* *$ & $* *$ \\
\hline
\end{tabular}

\section{Number of flowers per plant}

The number of flowers per plant is an important character which determines the yield of tomato fruit. Significant variation was observed between two varieties in case of number of flowers per plant. Higher number of flowers per plant was observed in BARI Hybrid Tomato-8 (38.11) compared to BARI Hybrid Tomato-4 (33.51) (Table 1).
There were significant variations in respect of the number of flowers per plant due to the application of plant growth regulators (Table 2). The maximum number of flowers per plant (45.88) was found in $\mathrm{T}_{3}$ treatment which was combined application of $\mathrm{GA}_{3}$ and 4-CPA. The minimum number of flowers per plant (22.52) was found in $\mathrm{T}_{0}$ treatment (control). There was no significant difference among the treatments and variety combination in respect of number of flowers per plant (Table 3). The 
production of flowers per plant may be affected by the cultivars and temperature. The variation between the two varieties in the present investigation is supported by Aung (1976) who reported an association of flower number with cultivars. . The number of flowers per plant increased due to the application of plant growth regulators.

\section{Number of fruits per plant}

Significant variation was found on number of fruits per plant between two summer tomato varieties (Table 1). Higher number of fruits (19.04) was produced by BARI Hybrid Toamto-8 compared to BARI Hybrid Tomato-4 (18.33). The plant growth regulators had significant influence on the number of fruits per plant (Table 2. The highest numbers (21.79) of fruits per plant were obtained from combined spraying of $\mathrm{GA}_{3}$ and 4-CPA while the lowest (12.09) numbers of fruits per plant were obtained fromthe control. The inter action effects of the treatments on the number of fruits per plant were significantly different (Table 3 ). The treatment $\mathrm{V}_{2} \mathrm{~T}_{3}$ gave the highest (21.91) number of fruits per plant over the treatment $V_{1} T_{0}$ (12.07) followed by the rest which were statistically different from each other. The treatment $\mathrm{V}_{1} \mathrm{~T}_{3}$ (21.66) and $\mathrm{V}_{2} \mathrm{~T}_{2}$
(21.54) were the second and third highest number of fruits per plant respectively. The lowest (12.07) number of fruits per plant was at $V_{1} T_{0}$ treatment.

Tomato plants exposed to high temperature reduce fruit set. Spraying with plant growth regulators increased the number of fruits per plant. Results of the study showed that under high temperature the combination of 4-CPA and $\mathrm{GA}_{3}$ induced higher number of fruit set to some extent. It has been reported that in an experiment with $20 F_{1}$ crosses, the tomato tone (trade name of 4-CPA) treatment had an appreciable effect on the number and weight of fruits of all lines (AVRDC, 1982). High temperature treatment decreases the levels of auxin and gibberellins-like substance, especially in floral buds and developing fruits of tomato. Therefore, shortage of auxin and gibberellins could cause the reduction of fruit set under high temperature. Application of 4$\mathrm{CPA}$ and $\mathrm{GA}_{3}$ presumably reduced the effect of high temperature and thus would have increased fruit set of tomatoes. Synthesized auxin and gibberellins are often used for promotion of fruit set in some fruit and vegetable production including tomatoes (Gemici et al, 2006; Khan et al, 2006; Serrani et al, 2007; Batlang, 2008).

Table 3. Interaction effect of plant growth regulators (PGRs) on growth, yield contributing characters and yield of summer tomato

\begin{tabular}{lccccccc}
\hline $\begin{array}{l}\text { Treatment } \\
\text { combination }\end{array}$ & \multicolumn{3}{c}{ Plant height $(\mathrm{cm})$ at } & $\begin{array}{c}\text { No. of } \\
\text { flowers. } \\
\text { Plant }^{-1}\end{array}$ & $\begin{array}{c}\text { No. of } \\
\text { fruits. } \\
\text { plant }^{-1}\end{array}$ & $\begin{array}{c}\text { Individual } \\
\text { Fruit. weight } \\
(\mathrm{g})\end{array}$ & $\begin{array}{c}\text { Yield } \\
\left(\mathrm{t} \mathrm{ha}^{-1}\right)\end{array}$ \\
\hline $\mathrm{V}_{1} \mathrm{~T}_{0}$ & 21.50 & 43.50 & 63.00 & 19.82 & 12.07 & 53.01 & 13.05 \\
$\mathrm{~V}_{1} \mathrm{~T}_{1}$ & 22.30 & 58.90 & 76.90 & 33.20 & 18.08 & 55.87 & 20.56 \\
$\mathrm{~V}_{1} \mathrm{~T}_{2}$ & 22.70 & 63.50 & 83.30 & 38.28 & 21.50 & 57.22 & 25.05 \\
$\mathrm{~V}_{1} \mathrm{~T}_{3}$ & 23.40 & 66.30 & 85.60 & 42.72 & 21.66 & 59.56 & 26.25 \\
$\mathrm{~V}_{2} \mathrm{~T}_{0}$ & 21.90 & 46.60 & 64.80 & 25.22 & 12.11 & 55.31 & 13.64 \\
$\mathrm{~V}_{2} \mathrm{~T}_{1}$ & 22.80 & 61.90 & 78.80 & 38.13 & 20.60 & 57.79 & 24.23 \\
$\mathrm{~V}_{2} \mathrm{~T}_{2}$ & 23.30 & 66.20 & 85.90 & 40.03 & 21.54 & 59.51 & 25.86 \\
$\mathrm{~V}_{2} \mathrm{~T}_{3}$ & 23.80 & 67.70 & 87.90 & 49.04 & 21.91 & 61.16 & 27.28 \\
\hline LSD (0.05) & 0.612 & 0.770 & 0.384 & 0.788 & 0.351 & 0.184 & 0.549 \\
\multicolumn{1}{c}{ (0.01) } & 0.849 & 1.068 & 0.533 & 1.093 & 0.486 & 0.255 & 0.761 \\
\hline Level of & $\mathrm{NS}$ & $*$ & $*$ & $* *$ & $* *$ & $* *$ & $* *$ \\
significance & & & & & & & $*$ \\
\hline
\end{tabular}

$\mathrm{V}_{1}$ and $\mathrm{V}_{2}$ indicate BARI Hybrid Tomato-4 and BARI Hybrid Tomato-8, respectively; $\mathrm{T}_{0}, \mathrm{~T}_{1}, \mathrm{~T}_{2}$ and $\mathrm{T}_{3}$ indicate control i.e. without PGRs, 4-CPA, $\mathrm{GA}_{3}$ and 4-CPA + GA 3 , respectively; NS, indicates non-significant; * and ** indicate significance at $5 \%$ and $1 \%$ level of probability; DAT indicates days after transplanting. 


\section{Individual fruit weight}

Significant variation was observed between the two summer tomato varieties in respect of yield (Table 1 ). The higher fruit weight $(58.44 \mathrm{~g})$ was obtained from BARI Hybrid Tomato-8 than BARI Hybrid Tomato-4 (56.42g). Plant growth regulators also had significant influence on individual fruit weight. The maximum yield (60.36 g) was obtained from combined application of 4-CPA and $\mathrm{GA}_{3}$, whereas the minimum (54.16 g) was from the control (Table $2)$. In case of combined effect, the treatment $V_{2} T_{3}$ gave the highest yield $(61.16 \mathrm{~g})$ whereas $\mathrm{V}_{1} \mathrm{~T}_{0}$ gave the lowest (53.01g). (Table 3).Ahmad (2002) also found variation in single fruit weight from $5.25 \mathrm{~g}$ to $43.38 \mathrm{~g}$ among 25 heat tolerant varieties which supports the findings of the present study.

\section{Yield}

Significant variation was observed between the two summer tomato varieties in respect of yield per hectare (Table 1). BARI Hybrid Tomato-8 gave higher fruit yield (22.75 $\mathrm{t} \mathrm{ha}^{-1}$ ) compared to BARI Hybrid Tomato-4(21.23 $\left.\mathrm{t} \mathrm{ha}^{-1}\right)$. Application of plant growth regulators had significant influence on fruit yield (t/ha) (Table 2). The highest (26.77 tha ${ }^{-1}$ ) fruit yield was obtained from the combined application of 4-CPA and $\mathrm{GA}_{3}$ and the lowest (13.35 tha ${ }^{-1}$ ) fruit yield was found in control treatment.

The interaction effects of varieties and plant growth regulator on the yield of tomato per hectare were highly significant (Table 3). It was observed that the highest (27.28 tha $\left.{ }^{-1}\right)$ fruit yield per hectare was found from the treatment combination of $\mathrm{V}_{2} \mathrm{~T}_{3}$, and the lowest yield (13.05 $\mathrm{t} \mathrm{ha}^{-1}$ ) was found from control plants.

Application of GA promoted cell growth and elongation leading to bigger plants with longer shoots and leaves which ultimately resulted with higher crop yields. Combined application of GA3 and 4-CPA increased the number of fruits per plant, single fruit weight and thus increased in yield of tomato.

\section{Acknowledgements}

We thank the Olericulture Division of Bangladesh Agricultural Institute for providing tomato seeds. The work was partly supported by the Ministry of Science and Technology, Government of the People's Republic of Bangladesh through the Special Allocation for Science and Technology under the project entitled "Development of Improved Production Technology for Summer Tomato in Bangladesh” (2014-2015/BS-29) to M. R. Karim.

\section{References}

Abdullah AA, Verkerk K (1968). Growth, flowering and fruit-set of the tomato at higher temperature. Neth. J. Agric. Sci. 16:71-76.

Ahmad S, (2002). Genetics of fruit set and related traits in tomato under hot-humid conditions. Ph.D. Thesis. BSMRAU. pp. 44 - 180.

Aung LH (1976). Effect of photoperiod and temperature on vegetable and reproductive responses of LycopersiconesculentumMill. J. Amer. Soc. Hort. Sci., 101:358-360.

AVRDC (1982). Progress Report. Asian Vegetables Research and Development Center, Shanhua, Tainan, Taiwan, pp. 19 - 54.

BARC (2012) Fertilizer Recommendation Guide2012. Bangladesh Agricultural Research Council, Farmgate, Dhaka. pp. 117.

Batlang U (2008). Benzyladenine plus gibberellins (GA4+7) increase fruit size and yield in greenhouse grown hot pepper (Capsicum annuumL.). J. Biol. Sci., 8(3): 659-662.

Gemici M, B Türkyilmaz, K Tan (2006). Effect of 2, 4-D and 4-CPA on yield and quality of the tomato, LycopersiconesculentumMill. JFS, 29: 24-32.

Gomez KA, AA Gomez (1984). Statistical Procedures for Agricultural Research. $2^{\text {nd }}$ edn.A Wiley-Interscience Publication.John Wiley and Sons.pp: 28192.

Khan MMA, AC Gautam, F Mohammad, MH Siddiqui, M Naeem, MN Khan (2006). Effect of gibberellic acid spray on performance of tomato.Turk. J. Biol., 30: 11-16.

Picken AJF (1984). A review of pollination and fruitset in tomato (Lycopersicone sculentum Mill). Hort. Sci. 59:1-13. 
Poliquit RD, MT Diputadu (2007). Tomato fruit parthenocarpy and yield increase in response to chlorophenoxyacetic acid. Ann. Trop. Res., 29(1): 14-25.

Sasaki H, T Yano, A Yamasaki (2005). Reduction of high temperature inhibition in tomato fruit set by plant growth regulators. JARQ, 39: 135-138.
Serrani JC, M Fos, A Atare's, JL Garc ${ }_{1}$ a-Mart $_{1}$ 'nez (2007). Effect of gibberellin and auxin on parthenocarpic fruit growth induction in the cv Micro-Tom 3 of tomato. J. Plant Growth Regul., 26: 211-221.

Wilcox J, G Catignani, C Lazarus (2003).Tomatoes and cardiovascular health.Crit. Rev.

Food Sci. Nutr., 43(1):1-18. 